\title{
THE EFFECTS OF STEM BLEEDING DISEASE ON THE FLOWERING AND FRUIT SETTING OF COCONUT HYBRID PB 121
}

\author{
J. Brahmana*
}

\section{SUMMARY}

Stem bleeding is one the common diseases of coconut in Indonesia. The severity of the disease varies considerably depending on the cultivars, environmental. factors, and the occurence of mechanical. damage on the stem.

Observation on the coconut hybrid PB 121 in the Bangun Purba estate PTP VI North Sumatra indicated that stem bleeding disease caused-necrosis in the stem tissue but it did not kill the tree. Moreover, this disease had no negative effects in the flowering, fruiting and inflorescence formation of the coconut tree.

\section{INTRODUCTION}

Stem Bleeding disease has been found in Indonesia and other countries such as India, Sri Lanka, the Philippines, Malaysia and Trinidad (J.L. Renard 1984). The organism responsible for it is the fungus Thielavipsis paradoxa (Ceratocystis paradoxa). The fungus is a weak parasite. It can only infect plants through cracksor wounds on the stem (Thampan, 1981). The field symptoms are the occurrence of "Bleeding" with dark brown color on the stem. If the area around the source of the bleeding was dissected or scraped, necrotic tissues were seen and frequently yellow coloured liquid with acid odour was observed. The fungus can attack plants of any age but it has been found attacking mainly coconut in production.

Some pathologists gave conflicting information on the effects of the Stem Bleeding disease. According to Loyola (1978) and Gapasin-(1982), Stern Bleeding disease in the Philippines could decrease yield and even kill the trees. However, observations in some areas in North Surnatra like Bangun Purba (PTP VI) and Aek Pancur (BPP Medan), with high rainfall intensity showed that in no case the stem bleeding disease had killed the plants. In Bangun Purba in 1984 the severity of the attack was dependent on the cultivar: on JBL $0.94 \%$, on JPY x JAB 1.56\% and on hybrid PB $1214.39 \%$ (see appendix 1).

$(\mathrm{JAB}=$ West African Tall $: \mathrm{JPY}=$ Polynesian Tall $: \mathrm{JBL}=$ Bali Tall $)$.

In Bah Lias, also an area with high rainfall in North Sumatra, some dead trees were found in some blocks showing severe $\mathrm{Cl}$ deficiency associated with stem bleeding (Annual Report, 1983). In East Indonesia region, Maluku, North and Central Sulawesi with a dry climate (Rainfall \pm 1300 $\mathrm{mm} /$ year, high water deficit $800 \mathrm{~mm} /$ year in 1982 until the beginning of 1983), some dead trees, with or without the disease, have been found (see appendix 2). On the demonstration plot in the Pandu Village, North Sulawesi 700 trees of coconut hybrid PB 121 were reported to have been attacked by stem bleeding but none was killed. In 1983-1984 the weather was normal again and most of the affected trees recovered (J. Warrow, personal communication).

In order to get more reliable information on this, disease, observations have been made on the effects of Stem Bleeding on the production of coconut hybrid PB 121 in Bangun Purba Estate (PTP VI).

* Pusat Penelitian Kelapa (Coconut Research Center) Bandar Kuala, North Sumatra, Indonesia. 


\section{MATERIALS AND METHODS}

The study was made on coconut hybrid PB 121 planted in the year 1977 located in Bangun Purba PTP VI during the first year (October, 1983 until September, 1984) and observation was made monthly. The design. was completely randornized with 5 treatments. Each treatment consisted of 30 trees. The treatments and their criteria were as follows:

a. Healthy trees $\mathrm{H},=$ trees with normal growth and not affected by Stem Bleeding disease.

b. $\quad$ Diseased trees $S=$ trees affected by Stem Bleeding, length of bleeding $=20 \mathrm{~cm}$, the fungus was still active and the trees have not been treated.

c. Diseased trees $P=$ trees affected by Stem Bleeding, length of bleeding $=20 \mathrm{~cm}$, the fungus was still active. The infected tissues were removed in August 1982, and subsequently treated with dithane M 45 .

d. Diseased trees $\mathrm{T}=$ trees affected by stem bleeding, length of bleeding $=20 \mathrm{~cm}$, the fungus was still active, surgery was done in June 1983. Fungicide treatments were done using Dithane M 45, Bayleton 250 EC, Derosol 60 Wp, Orthoside, Difolatan 4 F and Cuprafit OB 21.

e. Diseased trees $\mathrm{V}=$ trees affected by stern bleeding, length of bleeding $=20 \mathrm{~cm}$, the fungus was still active, the trees were injected with several fungicides in May 1983. Difolatan $4 \mathrm{~F}$, Cuprafit OB 21, Orthocide, Bayleton 250 EC, Benlate).

\section{Observation Method}

- $\quad$ First month : All spikes, spadices and bunches were numbered, starting from the lowest bunch (the oldest) till the most recently opened inflorescence. On each bunch/inflorescence, the number of nuts and female flowers were counted.

- $\quad$ From the second month onwards newly appeared inflorescences were noted and their female flowers counted. Each new inflorescence was numbered in sequence. The number of nuts present and female flowers per spikes which developed into nuts were counted (number of observed nuts=number of original nuts - number of aborted nuts).

- $\quad$ All changes on the stem and the leaves were also noted, among others are the development course of the bleeding, past attack (Oryctes and Rhincophorus), dead or fallen trees, etc.

\section{Data Processing}

The field data. were collected, processed and presented in the following components:

- $\quad$ Number of spadices and female flowers/tree/year

- $\quad$ Number of aborted female flowers/tree/3 months

- $\quad$ Number of aborted fruits/bunch/9 months

- $\quad$ Number of nuts harvested/tree/year

- $\quad$ Number of nuts on the trees at the beginning and at the end of the observation period.

\section{RESULTS AND DISCUSSION}

The effect of the stem bleeding disease were the following: 


\section{A. Number of Spadices and Female Flowers/tree/year}

Table 1: Number of spadices and female flowers/tree/year

\begin{tabular}{|c|c|c|c|c|c|c|}
\hline \multirow{2}{*}{ Treatment } & \multirow{2}{*}{$\begin{array}{c}\text { Number } \\
\text { of trees }\end{array}$} & \multicolumn{2}{|c|}{ Spadices } & \multicolumn{2}{|c|}{ Female Flowers } & Note \\
\cline { 3 - 7 } & 30 & 457 & 15.23 & 13.530 & 451.00 & Healthy \\
\hline $\mathrm{H}$ & 30 & 461 & 15.37 & 14.323 & 477.43 & $\begin{array}{c}\text { Diseased, } \\
\text { not treated } \\
\text { Diseased } \\
\text { treated } \\
\end{array}$ \\
& 30 & 449 & 14.97 & 13.268 & 442.27 & " \\
$\mathrm{P}$ & 30 & 471 & 15.70 & 14.991 & 499.70 & " \\
$\mathrm{T}$ & 30 & 467 & 15.57 & 16.481 & 549.37 & \\
$\mathrm{~V}$ & 150 & 2,305 & 15.37 & 72.593 & 483.95 & \\
\hline & & & & & & \\
\hline
\end{tabular}

The grand mean of all treatments was 15.37 spadices produced in 1 year. Statistical analysis showed that there were-differences among the treatments.

Treatment means of spadices and their separation using LSD 5\%

\begin{tabular}{|c|c|c|}
\hline Treatment & Mean values & Statistical notation \\
\hline $\mathrm{P}$ & 14.97 & $\mathrm{a}$ \\
$\mathrm{H}$ & 15.23 & $\mathrm{ab}$ \\
$\mathrm{S}$ & 15.37 & $\mathrm{abc}$ \\
$\mathrm{V}$ & 15.57 & $\mathrm{bc}$ \\
$\mathrm{T}$ & 15.70 & $\mathrm{c}$ \\
\hline
\end{tabular}

The results showed that treatment $\mathrm{H}$ (healthy trees) differed significantly only with the treatment $\mathrm{T}$ (diseased trees having undergone surgery) while it did not differ significantly with the other treatments (all diseased trees). The difference between the figures of treatment $\mathrm{H}$ and $\mathrm{T}$ was very small indeed (3\%) presurnably because of the difference in the potential of the trees. It can iherefore be concluded, the effects of stem bleeding disease on the production of spadices was insignificant.

The stem bleeding disease had also no effects on thenumber, of fernale flowers produced during 1 year observation period.

\section{B. Number of nuts harvested/tree/year}

Table 2: Number of nuts harvested/tree/year

\begin{tabular}{|c|c|c|c|c|c|c|c|c|}
\hline \multirow{3}{*}{ Treatment } & \multirow{2}{*}{\multicolumn{2}{|c|}{ Number of }} & \multicolumn{4}{|c|}{ Female flower } & \multirow{2}{*}{\multicolumn{2}{|c|}{ Aborted }} \\
\hline & & & \multicolumn{2}{|c|}{ At the Beginning } & \multicolumn{2}{|c|}{ At the End } & & \\
\hline & Trees & Spadices & Total & Mean & Total & Mean & Total & $\%$ \\
\hline $\mathrm{H}$ & 30 & 404 & 10.633 & 356.43 & 3.416 & 113.87 & 7.277 & 68.05 \\
\hline $\mathrm{S}$ & 30 & 399 & 11.142 & 317.40 & 3.507 & 116.90 & 7.635 & 68.52 \\
\hline $\mathrm{P}$ & 30 & 403 & 13.216 & 440.53 & 4.068 & 135.60 & 9.148 & 69.22 \\
\hline $\mathrm{T}$ & 30 & 414 & 12.241 & 408.03 & 3.756 & 125.20 & 8.485 & 69.32 \\
\hline V & 30 & 385 & 10.283 & 342.77 & 3.363 & 112.10 & 6.920 & 67.30 \\
\hline & 150 & 2410 & 57.575 & 383.83 & 18.110 & 120.73 & 39.465 & 68.55 \\
\hline
\end{tabular}

The statistical analysis shows that there was no difference between the treatments The disease did not affect the number of nuts harvested. 
Table 3: Number of aborted fruits/bunch/9 months

\begin{tabular}{|c|c|c|c|c|c|c|c|c|}
\hline \multirow{3}{*}{$\begin{array}{l}\text { Treat- } \\
\text { ment }\end{array}$} & \multicolumn{2}{|c|}{ Number of } & \multicolumn{4}{|c|}{ Nuts -9 months } & \multicolumn{2}{|c|}{ Aborted } \\
\hline & \multirow[b]{2}{*}{ Trees } & \multirow[b]{2}{*}{ Bunch } & \multicolumn{2}{|c|}{ At the beginning } & \multicolumn{2}{|c|}{ At the end } & \multirow[b]{2}{*}{ Total } & \multirow[b]{2}{*}{$\%$} \\
\hline & & & Total & Mean & Total & Mean & & \\
\hline $\mathrm{H}$ & 30 & 30 & 242 & 8.0 & 190 & 6.35 & 52 & 21.49 \\
\hline $\mathrm{S}$ & 30 & 30 & 234 & 7.80 & 194 & 6.50 & 40 & 17.09 \\
\hline $\mathrm{P}$ & 30 & 30 & 240 & 8.00 & 184 & 6.13 & 56 & 23.33 \\
\hline $\mathrm{T}$ & 30 & 30 & 251 & 8.36 & 203 & 6.76 & 48 & 19.12 \\
\hline \multirow[t]{2}{*}{$\mathrm{V}$} & 30 & 30 & 311 & 10.36 & 231 & 7.70 & 80 & 25.72 \\
\hline & 150 & 150 & 1278 & 8.52 & 1022 & 6.68 & 276 & 21.60 \\
\hline
\end{tabular}

The statistical analysis shows that there was no difference between the treatments

The stem bleeding had no effects on the fruit abortion during the 9 months period.

\section{Number of nuts harvested/tree/year}

Table 4: Number of nuts harvested/tree/year

\begin{tabular}{|c|c|c|c|}
\hline \multirow{2}{*}{ Treatment } & Number of trees & \multicolumn{2}{|c|}{ Harvested nuts } \\
\cline { 3 - 4 } & & Total & Mean \\
\hline $\mathrm{H}$ & 30 & 3.334 & 111.1 \\
$\mathrm{~S}$ & 30 & 3.137 & 104.6 \\
$\mathrm{P}$ & 30 & 3.306 & 111.2 \\
$\mathrm{~T}$ & 30 & 3.206 & 106.9 \\
$\mathrm{~V}$ & 30 & 3.356 & 111.9 \\
\hline & 150 & 16.339 & 108.93 \\
\hline
\end{tabular}

F. Number of Nuts on the Trees

The number of nuts on the trees at the beginning and at the end of observation period are:

Table 5: Number of nuts the trees

\begin{tabular}{|c|c|c|c|c|c|}
\hline \multirow{2}{*}{ Treatment } & \multirow{2}{*}{$\begin{array}{c}\text { Number of } \\
\text { trees }\end{array}$} & \multicolumn{4}{|c|}{ Number of nuts on the tree } \\
\cline { 3 - 6 } & & \multicolumn{2}{|c|}{ Total } & \multicolumn{2}{|c|}{ Mean } \\
\cline { 3 - 6 } & & Oct. 83* & Sept. 83 & Oct. 83* & Sept. 84 \\
\hline $\mathrm{H}$ & 30 & 3.161 & 2.809 & 105.37 & 93.63 \\
$\mathrm{~S}$ & 30 & 3.111 & 2.866 & 103.70 & 95.53 \\
$\mathrm{P}$ & 30 & 3.115 & 2.471 & 103.83 & 82.37 \\
$\mathrm{~T}$ & 30 & 3.254 & 3.105 & 108.47 & 103.50 \\
$\mathrm{~V}$ & 30 & 3.314 & 3.206 & 110.47 & 109.87 \\
\hline & 150 & 15.955 & 14.547 & 106.37 & 578.51 \\
\hline
\end{tabular}

* nuts older than 3 months

The statistical analysis shows that there was no difference between the treatments Stem bleeding did not affect the number of nuts on the trees in September 1983. 


\section{CONCLUSION}

(PTP Vl):

The following conclusions can be made from the results of the observations in Bangun Purba

1. Stem Bleeding disease did not affect the production of spadices and female flowers in 1 year.

2. The number of aborted flowers in 3 months and aborted fruits in 9 months were also not affected.

3. The number of nuts harvested and the number of nuts on the trees (that constituted the potential production) were also not affected by Stem Bleeding).

This common and widespread disease is thus not virulent, In farmers' small holdings the disease has been found frequently but the affected trees usually recovered without ever being treated.

As the disease had not affected the production, it can be further concluded that:

1. The functions of the destroyed interior stern tissues could be taken over by the more exterior parts

2. The causal organism, the fungus Thielaviopsis paradoxa did not produce any toxin.

However, we must be on the alert since this disease could be associated with other diseases which are more dangerous and virulent.

\section{REFERENCES}

1. Brahmana J. dan Witjaksana : Laporan kunjungan ke Sulawesi Utara dan Sulawesi Tengah. Doc 17/IV/1985 Pusat Penelitian Kelapa, Bandar Kuala P.O. Box. 16 Galang, Sumatra Utara.

2. Gapasin Dely P. Phd (1983) : Crop Protection Management on Coconut Lembaga Pendidikan Perkebunan (Medan, Indonesia.) P : 40.

3. Loyola Aracelia A. (1978): $\quad$ Stem Bleeding and control Extension Training Reference.

4. Ollagnier M and Wahyuni Mardiana (1984) : Mineral Nutrition and fertilization of the Malayan Dwarf x West Affican Tall (PB 121 -Mawa) Hybrid Coconut. Oleagineux, Vol.39 (8-9). September 1984. 0. 415-416.

5. Purba A (1983) : Laporan kunjungan ke Kelapa hibrida Tidore (Dewora) dan Ternate (Fitu) Doc. 13/VI/ 1983 Pusat Penelitian Kelapa, Bandar Kuala, P.O. Box.16 Galang, Sumatra Utara.

6. Purba A. dan J. Brahmana Penyakit Stem Bleeding pada kelapa hibrida PB 121. Sebuah laporan pengamatan. Doc. 23/VIII/1983 Pusat Penelitian Kelapa, Bandar Kuala, PO. Box 16 Galang Sumatera Utara.

7. Renard J.L., J. Brahmana (1984), F. Rognon : Performance of The Yellow West Affican Tall Hybrid coconut with regard to Stem Bleeding in Indonesia. 
Revelation of the role of chlorine in the expression of symptoms. Oleagineux, Vol 39 (6) Juni 1984. P : 311-312.

8. Thampan P.K (1981)

: Hand book on coconut palm Oxford \& IBH Publishing Co. New Delhi. P. 188-190. 